\title{
A Collection of Fragments, or a Fragment of a Collection? The Musical Appendix of A-Wn Cod. 5094
}

\begin{abstract}
The musical appendix of Vienna, Österreichische Nationalbibliothek Cod. 5094 contains ten polyphonic pieces and twenty plainsongs, written by twelve different hands in six different types of notation, including letter notation and early German organ tablature. It is not, however, a random collection of disiecta membra, rather an anthology (florilegium) for the use of organists, collected c.1443 by an Austin friar from Munich visiting Vienna, who owned the parent codex.
\end{abstract}

\section{The surviving material}

Archaeological excavations often start with casual findings of small objects such as pottery shards or coins, which may be dispersed over a wider area in the ground. What the specialists then reconstruct from these remains, is usually a larger unit: a single house or a large estate, a Roman villa, a military camp, a village or a town. The question is how to get from the fragments to the hypothetical larger unit. Well-known strategies of reconstruction are the following:

- First, drawing conclusions as to the lost parent unit from the materiality of the surviving material: the paper type, the pottery material, etc.

- Second, comparing the transmissional contents of the material with evidence elsewhere: the forms and styles of the pottery, the notation or genres of the music, the identity of the musical pieces, etc.

- Third, if more than one item has been found, interrogating the spatial, material, and possibly cognitive relationship between the surviving items, for

\footnotetext{
Note: A shorter, German version of this chapter is also available in the online project Musical Life of the late Middle Ages in the Austrian Region, c.1340-c.1520, <https://musical-life.net/ essays/a-wn-cod-5094-souvenirs-aus-einem-wiener-organistenmilieu/ $>$. See also Reinhard Strohm, <https://musical-life.net/kapitel/zeugnisse-einer-wiener-organistenwerkstatt-wn-cod-5094>; Klaus Aringer, <https://musical-life.net/kapitel/fragmente-einer-wiener-organistenwerkstatt> (all websites quoted in this article have been last accessed 15 Sept. 2020).
}

Ә Open Access. ( 2020 Reinhard Strohm, published by De Gruyter. (cc) BY-NC-ND This work is licensed under the Creative Commons Attribution-NonCommercial-NoDerivatives 4.0 International License.

https://doi.org/10.1515/9783110717884-010 
example by finding two broken edges that fit precisely together, or a verbal sentence in one fragment that is continued in another - just as in a puzzle.

- Fourth, considering whether these relationships may point to an original larger unit, and whether this unit may have been disturbed in later times, for example by assembling fragments that belonged to different original units.

- And fifth, if due to accidents of transmission the surviving bits did not originally form a single unit, asking why they are found together. What other denominator might they have in common? When did they belong together, and in what context? To identify a common denominator presupposes a cultural interpretation, for example by suggesting an institution, a person, a practice that was responsible for the collection.

The musical appendix of Cod. 5094 of the Austrian National Library in Vienna raises many of these questions. The source is, at first glance, an almost random collection of eighteen paper leaves, bound as ff. 148-164 at the back of the main codex (on which, see below). An eighteenth- or nineteenth-century ink foliation, no longer visible on all pages, has been complemented by a twentieth-century pencil foliation; the originally unfoliated second leaf received the number $148 \mathrm{a}$ only in pencil foliation. ${ }^{1}$ These leaves contain various forms of musical notation. Only one of the leaves (f. 156) has no music: it is not part of the musical collection but belongs to the first section of the main codex, with which it also shares its scribal hand and watermark. The paper sizes vary, the main and largest size being of $31 \times 22 \mathrm{~cm}$, which matches that of the main codex. The leaves were perhaps cut to size - although no music leaf shows any writing loss through cropping. As far as the tight binding allows to judge this, we have only one bifolium (ff. 154-155) and one group consisting of a bifolium and a single leaf (ff. 160-161, f. 159); the other components are all single leaves, each with individual contents. This is corroborated by the presence of, at least, twelve different paper types. Visible watermarks are 'Scales without circle' (f. 148), 'Anvil in circle' (ff. 148a and 152), 'Mountains with cross' (ff. 154-155), 'Stag with cross' (ff. 159, 160-161), 'Oxhead with cross' (f. 163), 'Mountains with two flowers' (f. 164): these paper types all seem to belong to the 1440 s. Where no watermark is visible, the papers are distinguishable by their colour and thickness. ${ }^{2}$

1 F. 148a was probably not added after the ink foliation had been entered, but was not counted at first because it is of irregular size, being cropped to an almost square shape.

2 A detailed attempt at identifying and dating the paper types has not yet been undertaken, but the available data may suffice for the present analysis. 
The binder has turned one leaf upside down (f. 148a), reversed two (ff. 158, 162) and bound one before, instead of after, its related bifolium (ff. 159; 160-161). The bifolium 154-155 is notated in oblong (landscape) format. ${ }^{3}$ Importantly, several leaves had originally been folded, some only once horizontally, others twice and even three times horizontally and vertically. The landscape format and the folding may be clues to the original uses of the music (see Table 1). ${ }^{4}$

On the evidence presented thus far, these leaves are not fragments of one larger manuscript. However, since, several of them are connected through their musical contents, scribal hands, notational types, and the roughly coeval watermark types, an entirely random assembly also seems improbable.

Table 1: A-Wn, Cod. 5094, ff. 148-164: paper, rastrum, copyists, notations.

\begin{tabular}{|c|c|c|c|c|}
\hline Folio & Paper type & Rastrum & Copyist & Notation \\
\hline 148r blank & $\begin{array}{l}\text { 1: scales without } \\
\text { circle }\end{array}$ & & & \\
\hline $148 v$ & & $9 \times 5$ & A (larger script) & MN full \\
\hline 148ar blank & $\begin{array}{l}\text { 2: anvil in circle, } \\
\text { cropped, } \\
\text { folded once }\end{array}$ & & & \\
\hline $\begin{array}{l}\text { 148av bound } \\
\text { upside down }\end{array}$ & & $8 \times 5$ & B (Chranekker) & MN void and full \\
\hline $149 r$ & 3; folded twice & $18 \times 4$ & A (small script) & $\mathrm{CN}$ \\
\hline $149 v$ & & $18 \times 4$ & A (small script) & $\mathrm{CN}$ \\
\hline $150 \mathrm{r}$ & $3 ;$ folded 3 times & $9 \times 6(!)$ & $\mathrm{C}$ & SN full \\
\hline $150 v$ & & $9 \times 6(!)$ & $\mathrm{C}$ & SN full \\
\hline $151 \mathrm{r}$ & 4; folded once & $11 \times 4$ & $\mathrm{D}$ (pen trials) & $\mathrm{CN}$ \\
\hline $151 v$ & & $11 \times 4$ & $E$ or $A$ & $\mathrm{CN}$ (cantus fractus) \\
\hline $152 r$ & 2; folded once & $19 \times \times 4$ & A (small script) & $\mathrm{CN}$ \\
\hline $152 v$ & & $18 \times 4$ & A (small script) & $\mathrm{CN}$ \\
\hline $153 r$ & 5 ; folded once & $10 \times 4$ & $\mathrm{~F}$ & $\mathrm{CN}$ \\
\hline 153v blank & & & & \\
\hline
\end{tabular}

3 Facsimile in https://musical-life.net/mediengalerie.

4 Abbreviations: $\mathrm{C}=$ Cantus, $\mathrm{T}=$ Tenor, $\mathrm{Ct}=$ Contratenor, $\mathrm{MN}=$ mensural notation (full or void), $\mathrm{CN}=$ chant notation, $\mathrm{SN}=$ stroke notation (full or void), $\mathrm{OT}=$ (early German) organ tablature, $\mathrm{LN}$ = letter notation, frg. $/$ frgs $=$ fragment/s, clefs: $\mathrm{c1}, \mathrm{c3}, \mathrm{f3}$, f4, etc. 
Table 1 (continued): A-Wn, Cod. 5094.

\begin{tabular}{|c|c|c|c|c|}
\hline Folio & Paper type & Rastrum & Copyist & Notation \\
\hline $154 \mathrm{r}$ blank & $\begin{array}{l}6 ; \text { mountains with } \\
\text { cross }\end{array}$ & & & \\
\hline $154 \mathrm{v}$ & & $4 \times 5$ landscape & G & SN \\
\hline $155 r$ & 6 & $4 \times 5$ landscape & G & MN, SN \\
\hline $155 v$ & & $4 \times 5$ landscape & G & $\begin{array}{l}\text { SN, LN, } \\
\text { 9-line staves }\end{array}$ \\
\hline $156 r-v$ & 7 & none & $\begin{array}{l}=\text { Cod. } 5094, \\
\text { f. } 1 \mathrm{r}-3 \mathrm{v}\end{array}$ & none \\
\hline $157 r$ & 8 & $6 \times 5$ & $\mathrm{H}$ & CN (cantus fractus) \\
\hline $157 v$ & & $\begin{array}{l}4 \times 5 \text { (lower half } \\
\text { only) }\end{array}$ & $\mathrm{D}$ (pen trials) & $\mathrm{CN}$ \\
\hline $158 r$ & 2(?); folded once & $\begin{array}{l}9 \times 5 \text {, barlines } \\
\text { over entire page }\end{array}$ & 1 & OT \\
\hline $158 \mathrm{v}$ & & $\begin{array}{l}9 \times 5 \text {, barlines } \\
\text { over entire page }\end{array}$ & 1 & OT \\
\hline $159 r$ & 9; stag with cross & $10 \times 5$ & J & $\begin{array}{l}\mathrm{CN} \text { (belongs to } 160 \mathrm{r}- \\
161 \mathrm{v})\end{array}$ \\
\hline \multicolumn{5}{|l|}{$159 v$ blank } \\
\hline $160 r$ & 9 & $9 \times 5$ & J & $\mathrm{CN}$ \\
\hline $160 v$ & & $9 \times 5$ & J & $\mathrm{CN}$ \\
\hline $161 \mathrm{r}$ & 9 & $9 \times 5$ & J & $\mathrm{CN}$ \\
\hline $161 \mathrm{v}$ & & $9 \times 5$ & J & $\mathrm{CN}$ \\
\hline $162 r$ & 10 & $7 \times 5$ & $\mathrm{~K}$ & $\begin{array}{l}\text { MN full (cantus } \\
\text { fractus, note-value } \\
\text { dots) }\end{array}$ \\
\hline $162 v$ & & $7 \times 5$ & $\mathrm{~K}$ & $\begin{array}{l}\text { MN full (cantus } \\
\text { fractus, note-value } \\
\text { dots) }\end{array}$ \\
\hline $163 r$ & $\begin{array}{l}11 ; \text { oxhead with } \\
\text { cross }\end{array}$ & $7 \times 5$ & $\mathrm{~L}$ & MN full \\
\hline $163 v$ & & $7 \times 5$ & $\mathrm{~L}$ & $\begin{array}{l}\text { MN full (note-value } \\
\text { dots) }\end{array}$ \\
\hline $164 r$ & $\begin{array}{l}\text { 12; mountains } \\
\text { with two flowers }\end{array}$ & $9 \times 5$ & $M$ & MN void \\
\hline $164 \mathrm{v}$ & & $9 \times 5$ & M & MN void \\
\hline
\end{tabular}




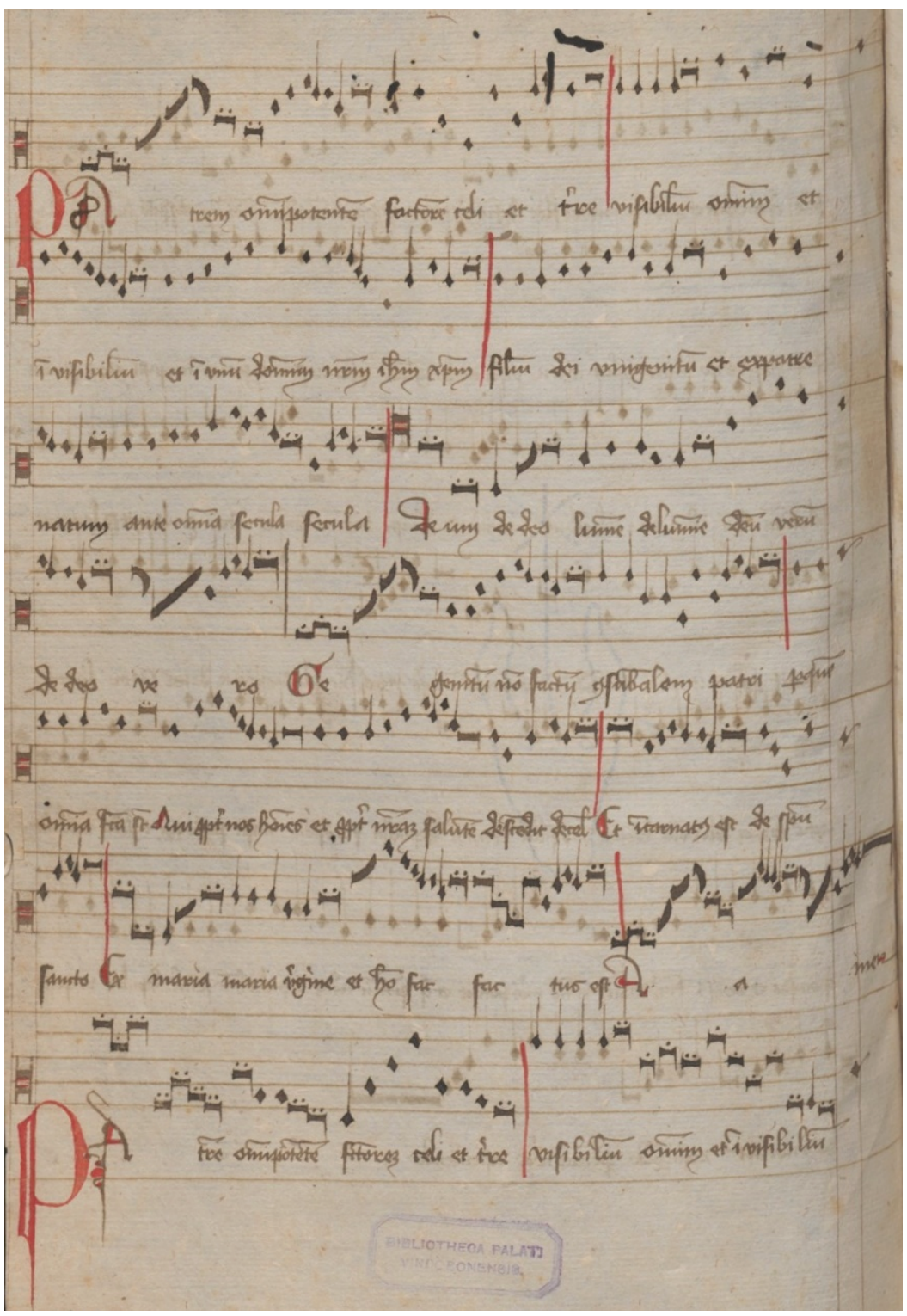

Fig. 1: Note-value dots for sacred music (plainsong in cantus fractus polyphony), A-Wn, Cod. 5094, f. 163v; (C) Vienna, Österreichische Nationalbibliothek. 


\section{The musical contents}

As shown in Table 1, we find either twelve or thirteen different music hands and many different notational genres: mensural full and void, mensural with notevalue dots (see Fig. 1), chant notation (gothic, so-called 'Bohemian-Messine' notation, and square), early German organ tablature, stroke notation and letter notation, cantus fractus (partially-measured chant notation)..$^{5}$ One notator (A) adopts two different script sizes (see ff. 148, 149 and 152).

What sort of collection is this? Would someone unfamiliar with the musical styles have been likely to assemble, in such a restricted space, so many different types of notation, and musical genres, as will be seen? There is here a measure of musical communality and perhaps common agency. Hand A, for example, uses full and void mensural notation for polyphony and chant notation of a much smaller size for plainsong: this musician was multi-tasking. Hand $\mathrm{G}$ brings together stroke and letter notation on the same page. The two notations are demonstrated with two versions of the same sample piece: a three-voice Ave maris stella - the same piece which hand A notates on a different page in void mensural notation. Hands A and G are present together on one page (f. 155v).

The musical contents, ordered by scribal hands, may be listed as follows:

Hand A (larger script)

f. 148v (leaf bound upside down, preceding leaf lost): 3-voice Skack sive celsito[nanti] (Froleich geschrai, Oswald von Wolkenstein), present only $\mathrm{Ct}$ (f3) and T (f3), MN full; Virginem mire (En discort, anonymous Ars Nova ballade), frg. T (f3), MN full; 3-voice Ave maris stella $=$ f. 155v, MN full. ${ }^{6}$

f. 155v bottom (landscape layout): 3-voice Ave maris stella $=$ f. 148v, frg., SN void (9-line stave) and twice in LN (second time frg.).

5 On note-value dots ('Notenwertpunkte'), see Bernhold Schmid, <https://musical-life.net/ kapitel/weitere-notationssysteme-im-codex-5094>. On cantus fractus as a polyphonic plainsong performance, see Marco Gozzi, 'Rhythmischer choralgesang: der Cantus fractus', <https://musicallife.net/essays/rhythmischer-choralgesang-der-cantus-fractus>. Examples from Cod. 5094 in Bernhold Schmid, <https://musical-life.net/kapitel/weitere-notationssysteme-im-codex-5094>. 6 Facsimile in <https://musical-life.net/kapitel/ave-maris-stella-im-wiener-codex-5094>. 
Hand $A$ (small script)

ff. 149r-v, 152r-v: 1-voice Sequences for Dorothea, Catherine, Maria, Michael, Ulrich (adapted for Wolfgang and Rupert), Church dedication, Easter (CN).

Hand B (Wolfgang Chranekker) ${ }^{7}$

f. 148av (leaf bound upside down): 3-voice textless (Ce jour le doibt, Du Fay), MN void and full, in score on two staves. ${ }^{8}$

Hand C

f. 150r: 2-voice textless frg., perhaps a draft for the Salve regina, f. 150v, SN full.

f. 150v: 3-voice Salve regina, present only C (c2), Ct (c5), SN full. Following leaf lost.

Hand D

ff. 151r, 157v: musical pen trials (square $\mathrm{CN}$ ).

Hand $E$ (or $A$ ?)

f. 151v: 1-voice Gloria Primogenitus Marie (CN, cantus fractus), two Kyries, one frg. Sanctus (CN). Following leaf lost.

\section{Hand F}

f. 153r: 1-voice Introitus In Nicolai transitu, Alleluia Stabit Nicolaus (square $\mathrm{CN})$.

\section{Hand $G$}

ff. 154r-155r (landscape layout): 4-voice Segnier Leon / Benedictus qui venit (Du Fay, 1442), SN void.

f. 155v top (landscape layout; different text hand?): 3-voice Ave maris stella $=$ f. 148v, SN void; f. 155v bottom: see hand A.

\section{Hand $H$}

f. 157r: 1-voice Sanctus-Agnus Dei, CN, cantus fractus, end missing.

\section{Hand I}

f. 158r-v (bound in reverse): 3-voice textless 'rundelus' (ars nova motet Apollinis eclipsatur, B. de Cluny), OT.

7 On Chranekker, see below.

8 'Italian organ tablature', a term apparently introduced by Willi Apel for mensural score notation, would technically look similar, but the present notation in score with one voice being distinguished by full red or black notes is found in Italy and Central Europe for polyphonic plainsong; see, for an example, Strohm 1966. 


\section{Hand J}

ff. 159r, 160r-v, 161r-v (begins f. 160r, preceding leaf lost): 1-voice plainsongs for Barbara and Mary, CN.

\section{Hand $K$}

f. 162r-v (reversed): two 1-voice Credo, one of which frg., MN full, note-value dots.

Hand $L$

f. 163 r (preceding leaf lost): 1-voice frg. ...solem qui te rexit (O Maria pya, Monk of Salzburg, contrafactum of his Ju ich jag,), MN full.

f. 163v: 2st. frg. Credo, melody = f. 162r, MN full, note-value dots. Following leaf lost.

\section{Hand $M$}

f. 164r: 2-voice Vivat nobilis prosapie, MN void.

f. 164v: frg. textless draft of a cantus [c1?]; 2-voice textless piece (f3, f3), MN void.

Pages without musical content:

ff. 148r, 148ar, 151r ('Historia de Sancto Livino episcopo et martire', pen trials), 153v, 154r, 157v (liturgical texts, musical pen trials), 159v. F. 156r-v belongs with the main codex (ff. 1-3).

As could be expected, the notational variations often relate to the nature of the music, but this is not always so: the three-voice Ave maris stella is copied by scribe A in mensural notation, and by scribe $G$ in three 'instrumental' types of notation, suggesting systematic variation and collaboration between individuals. It seems to be a learning process in musical notation, with a single piece as a sample. The Salve regina on $\mathrm{f} .150 \mathrm{v}$ is preceded on $\mathrm{f} .150 \mathrm{r}$ by an incomplete copy by the same hand, possibly a composition draft; the motet-like piece on f. $164 \mathrm{r}$ may be related to a compositional sketch by the same hand on $\mathrm{f} .164 \mathrm{v}$ (stave 7).

Notator B is Wolfgang Chranekker, who was organist in St Wolfgang am Abersee in 1441; his name and identity have been discovered by Peter Wright, after Tom Ward had noted the concordance of the scribal hand in the St Emmeram codex. ${ }^{9}$ Chranekker wrote the chanson Ce jour le doibt in a pseudoscore on two staves, a notational type that is technically similar to what we now call '(early) Italian organ tablature', although the score notation and the use of full notes to distinguish a contrapuntal voice are well-known in Italian and

9 On Chranekker, see Rumbold/Wright 2009, 98-107. 
German 'simple' polyphony of the late Middle Ages, usually performed vocally. It is striking that about a third of the musical material in Cod. 5094 uses 'marginal' notational systems such as stroke notation, cantus fractus, tablature, note-value dots - and that all these notations are written by five different hands. There seems to have been a common interest in types of music that are unusual for us today. Since the items do not stem from a common manuscript or author and yet, seem to be assembled with a common focus, what we have here may not be scattered body-parts (disiecta membra), but rather an anthology (florilegium).

\section{Users}

Frederick Crane (1965) and Theodor Göllner $(1967)^{10}$ realised the challenge of apparent heterogeneity in this source. Whereas Crane discussed only the tablature items, taking them as specimens of a more widely diffused practice (which they presumably are), Göllner gave the collection and the practice it represents, a common name: Notationsfragmente aus einer Organistenwerkstatt (notational fragments from an organist's workshop); he could have meant the word 'Organisten' either in the singular or in the plural. But what is an 'organist's (or organists') workshop'? Is it the rood-loft of a church? And what is supposed to happen there? As regards to performance, the leaves notated in landscape layout (ff. 154-155) might fit on an organist's desk, but instead of a tablature they contain letter notation and stroke notation in pseudo-score and choirbook layouts. The choirbook layout of the four-voice Segnier Leon on these pages could be played from, if the two adjacent leaves were placed side by side of each other on the desk, which would only be possible if the bifolium were cut in two single leaves.

The apparent potential for instrumental playing - whether on the organ or other instruments - is not the only common denominator of the collection. Transcriptional exercises point to study and rehearsal; even the 'instrument-related notations' such as letter notation, tablature and score notation seem to have served didactic or study purposes. Two sketchlike items seem to be composition trials (hand C, f. 150, and hand M, f. 164). Heinz Ristory (1985) described the transformations of the Ave maris stella as a 'notational exercise';1 Bernhold Schmid in his contribution to the online project Musikleben des Spätmittelalters

10 Crane 1965; Göllner 1967, 170-77.

11 See Ristory 1985. 
in der Region Österreich (1340-1520) (2016) also emphasised the notational peculiarities. ${ }^{12}$

There is, in addition, the fact that the music is written mostly on single leaves, and sometimes left incomplete or transmitted in an incomplete form. This fragmentation apparently did not happen by force, as when a leaf is torn into two, but rather by the simple loss of a complementing leaf, as if it had accidentally fallen from a table, for example. The material may be of heterogeneous provenance, but it seems to have been brought together not by tearing out fragments from their parent contexts, but by consciously transferring discreet materials in single-leaf form from their original contexts to make more use of them here. The folded leaves imply that the material has travelled or was sent as a letter: this evidence invites speculation about who the users were and what purposes the music had for them.

In 1984, I published a complete handlist of the collection with provisional identifications of the music, and an attempt at distinguishing the scribal hands; this exercise suggested that we are really dealing with an ecclesiastical collection, because eleven of the eighteen leaves contain liturgical vocal music. ${ }^{13}$ These are often notated in a very small script, so that many long chants fit on a few pages. No schola could read from this, but an organist might play from this 'organ plainsong notation'. ${ }^{14}$ This vocal material could have served for instrumental performance, whereas the instrumentally-transcribed material, vice-versa, rather suggests study and learning. Other liturgical items are either set in simple polyphony, or as cantus fractus, a significant fifteenth-century vocal practice. The three-voice Salve regina is written entirely in semibreves ('stroke notation'), containing a few intermittent phrasing dashes without mensural function, and final longs. ${ }^{15}$ Although unmeasured, this seems a highly professional setting of the plainsong in three-voice chanson format.

Not all of the music is sacred in origin. The six secular compositions are, however, presented as Latin contrafacta or have original Latin texts. Even Du Fay's Segnier Leon, with a two-word French incipit has, exceptionally, a Latin liturgical tenor text, Benedictus qui venit. Taking these observations together and asking for a common characterisation, Göllner's term ‘Organistenwerkstatt' remains per-

12 Bernhold Schmid, 'Ave maris stella im Wiener Codex 5094', in <https://musical-life.net/ kapitel/ave-maris-stella-im-wiener-codex-5094>.

13 See Strohm 1984.

14 For a facsimile, see Reinhard Strohm, 'A-Wn, Cod. 5094: Souvenirs aus einem Wiener “Organistenmilieu”', 2018, <https://musical-life.net/essays/wn-cod-5094-souvenirs-aus-einemwiener-organistenmilieu>.

15 On stroke notation, see Van Biezen/Vellekoop 1984 and Strohm 1993, 352-357. 
suasive, as long as we bring all the material into play that is present here, and enquire about the nature of organists' duties at the time.

\section{External relations of the music}

Let us consider the chronological, repertorial and geographical context of the collection. The watermark types are all compatible with the 1440s; Hand B (Chranekker) is documented in 1441 and was probably active in Vienna in the preceding years. Musical concordances lead further. The motet Apollinis eclipsatur seems to have reached Austria early in the century: it is also found in A-Wn, Cod. 922, a fragment of a fourteenth-century liber motetorum. ${ }^{16}$ Virginem mire pulchritudinis, a contrafactum of the virelai En discort, was well-known in the region and popular with organists and theorists; it is mentioned, for example, by the Melk Anonymus in MS 950 of Melk Abbey, a copy dated 1462. ${ }^{17}$ Du Fay's ballade Ce jour le doibt may be of the 1420s; it is transmitted in the Trent codices. ${ }^{18}$ The youngest datable composition is Du Fay's Seigneur Leon, probably composed in Ferrara in $1442 .{ }^{19}$ We also find 'Skack sive celsitonanti', a contrafactum of Oswald von Wolkenstein's Froleich geschrai, but with the additional label 'skak', which in my opinion refers to the exchiquier or Schachtpret; the same label appears in the copy of the original song in Oswald's manuscript A, of $c .1425$, which in 1447 belonged to Duke Albrecht VI of Austria. ${ }^{20}$ The fragment beginning ...solem qui te rexit on $\mathrm{f}$. $163 \mathrm{r}$ has been identified by Michael Shields as part of the contrafactum O Maria pya of the Monk of Salzburg's Singradel Ju, ich jag. ${ }^{21}$ The interest of Hands A and G in three-voice versions of the hymn Ave maris stella is analogous to the appearances of several similar settings of this hymn in Hermann

16 On the fragment Cod. 922 see Cuthbert 2010.

17 On Virginem mire puchritudinis/En discort, see Strohm 1993, 122-124.

18 For facsimiles and transcription of Ce jour le doibt, see Klaus Aringer, <https://musicallife.net/kapitel/fragmente-einer-wiener-organistenwerkstatt>, with facsimiles; Bernhold Schmid, $<$ https://musical-life.net/essays/organisten-und-kopisten $>$.

19 See Fallows 1987, 62-63. Facsimile in <https://musical-life.net/mediengalerie>; a recording of the song by the Ensemble Leones is in <https://musical-life.net/audio/seigneur-leon $>$.

20 See Strohm 1984, 212-213.

21 Shields 2011, 131-147. 
Pötzlinger's section of the St Emmeram codex (Vienna, c.1439). I believe that all these three-voice hymn settings served as compositional exercises. ${ }^{22}$

The Mass ordinary melodies and cantus fractus settings generally belong to the Bavarian/Austrian repertories of the time; the sequence Psallat concors symphonia for St Dorothy may suggest the Passau diocese and perhaps Vienna, where this saint was particularly venerated and this sequence text was current. The sequence Gloriosa fulget dies offers a more specific clue: its underlaid text is formulated here for St Udalricus of Augsburg, but it has also been adapted by the main scribe (hand A) for the Passau diocese (patavia) and for Saints Wolfgang of Regensburg and Rupert of Salzburg. ${ }^{23}$ This scribe apparently copied the piece first in a place connected to Augsburg and later adapted it for a location further east. Gloriosa fulget dies was normally used for Sts Nicholas and Augustine, and in the Passau diocese specially for its patron St Valentin. The pilgrimage church of St Wolfgang am Abersee (= Wolfgangsee), where Chranekker was organist, also belonged to the Passau diocese at that time.

Wolfgang Chranekker showed great competence in void mensural notation in the St Emmeram codex, to which he contributed the latest section around 1441-1443. Johannes Lupi, organist at Trent cathedral from 1447, left only mensural notation in his sections of the Trent codices. ${ }^{24}$ His successor in compiling these manuscripts, Johannes Wiser, may have been an organist previously. ${ }^{25}$ The status of fifteenth-century organists may have to be redefined: these individuals were often academics, all-rounders in music, and teachers. Their daily practice would suit a sacred institution where the organist taught and directed not only other organists (his private pupils), but also singers, even the general choir. The plainsong performances in smaller institutions such as monasteries and friaries would have taken place around the organist's desk; evidence that organists played much of the plainsong, especially hymns, the Mass ordinary and votive antiphons, is as frequent in Austria as in other parts of Europe including England. ${ }^{26}$ Organists were highly respected: when Conrad Paumann from Munich visited Vienna in 1452, he was well paid by the magistrate and carried around on

22 In the forthcoming essay 'Kompositorische Lernprozesse' (<https://musical-life.net/essay/ kompositorische-lernprozesse >), I aim to explain some procedures of sample composition that are involved here.

23 Facsimile in $<$ https://musical-life.net/mediengalerie $>$.

24 Reinhard Strohm, 'Johannes Lupi', in <https://musical-life.net/essays/johannes-lupi/>.

25 The mention of 'Iohannes organista de Monaco', at Vienna University in 1454, was first observed in Pietzsch 1971, 186.

26 See Klaus Aringer, in <https://musical-life.net/essays/orgeln-und-orgelmusik-der-regionoesterreich>. 
a chair in the Corpus Christi procession. ${ }^{27}$ The collectors of the musical material in Cod. 5094 were presumably well-connected musicians.

\section{The parent codex}

It is, however, the relationship of the musical appendix to its parent codex that can throw further light on the origins of this collection. The corpus of Cod. 5094 is even more miscellaneous and seemingly heterogeneous than the musical appendix. It belongs to the type of manuscript the Italians called zibaldone, a commonplace book of useful texts and citations.

The codex is supposed to have belonged to the sixteenth-century physician and historian Wolfgang Lazius (1514-1565) at the University of Vienna, with the shelfmark 'Jur. can. 49'. In 1752 it was bound, including its musical appendix, for the Vienna Hofbibliothek under court physician and librarian Gerard van Swieten, whose initials are stamped on the leather binding. The Tabulae codicum of the Austrian National Library $(1870)^{28}$ divide the contents of the corpus in nine distinct sections, but in reality there are at least forty. A great variety of papers is present; written original datings range from 1411 to 1463 . The contents are extracts from treatises, papal bulls, copies of charters and letters on subjects of canon law, enriched with personal letters, epigrams, humanist model verses, extracts from Prudentius' Metra de S. Monica (f. 140r) and a Latin dictionary of episcopal sees (ff. 134r-135v). Many letters are originals, folded for dispatch and occasionally carrying remnants of seals. Other letters are copies, drafts or templates (model texts). Several charters and letters are translated into German. The sections on ff. 1-57 are excerpted from Decrees of the Council of Constance; hence the volume was entitled Acta concilii constantiensis in 1752. Many documents concern the order of the Austin Friars (Ordo Eremitarum S. Augustini, OESA), particularly its Munich house; there are also links to other Augustinian houses and to Minorites, the latter for example at Nuremberg, 1448 (f. 126r). The Austin friar Berthold of Regensburg (Berthold Puchhauser) writes from Vienna to members of the Munich house, on 24 November 1411 (f. 128r), and again, from Regensburg, in 1421 (ff. 141r-142r). Georg von Schöntal, Provincial of the Austin friars in Bavaria and Austria, writes from Vienna to a certain "Jorgen N. de N."

27 Reinhard Strohm, 'Städtisches Musiklebe', in <https://musical-life.net/essays/städtischesmusikleben>.

28 Mantuani 1864-1899, IV. 
concerning his admission to the order (f. 122r, a model text). Knight Berthold von Stain, who founded an Augustinian friary at Uttenweiler (Upper Swabia), writes to the Munich convent in 1456 (f. 143r). There is some correspondence with a young Augustinian brother, Maurus Venetus, who is studying in Padua (f. 145rv). A recurring topic is the practice of dispensing holy sacraments; the copyist one of these texts, on the eucharist, names himself Nicolaus Mewerl (f. 138v).

Because of its links to the Austin friars of Munich, Göllner and others have proposed that the entire manuscript including its musical appendix originated in that house. But there are no such links in the musical appendix, which is more clearly situated in an Austrian context. Even some documents in the main codex concern the University of Vienna and the Habsburgs. Several letters are by Pope Pius II (Enea Silvio Piccolomini), former secretary of King Frederick III. In one of these, Piccolomini informs the University of Vienna of his election to the papacy, 1458 (f. 124r). F. 139r-v is a fragmentary copy of a missive by King Albrecht II of Habsburg (c.1438). A document on $\mathrm{f}$. 136v concerns a legal dispute between the mendicant friars and professors of the University of Vienna with the choirmaster (senior curate) of St Stephen's church in the early 1440s. This notarial copy (Vidimus) of a charter, written in Vienna on 8 February 1443, leads us to the probable original owner of Cod. 5094 and the all-important connection between its main corpus and appendix.

\section{The original owner of the music collection?}

The legal dispute was about the rights of mendicant friars to dispense the holy sacraments and hear confessions in the collegiate church of St Stephen's, Vienna. Shortly after 1440, the choirmaster Lienhard Orthaber had attempted to ban the friars of the four mendicant orders entirely from his church. The friars protested, presumably because hearing confession and dispensing the holy sacraments were important sources of income from wealthy parishioners.

Many mendicants were members of the university, so that the dispute was carried out between the university and the collegiate church. The charter sets down an apparent final verdict, specifying the conditions under which the friars were allowed to hear confessions and dispense holy sacraments in the church of St Stephen's: they could do so only by special permission from the parish clergy. It was a compromise: rather than being banished from the church altogether, the friars would have been happy to ask for special permissions. The document on 
f. 136v, a notarial transcript (Vidimus) of an original charter, is reproduced here in Fig. 2.

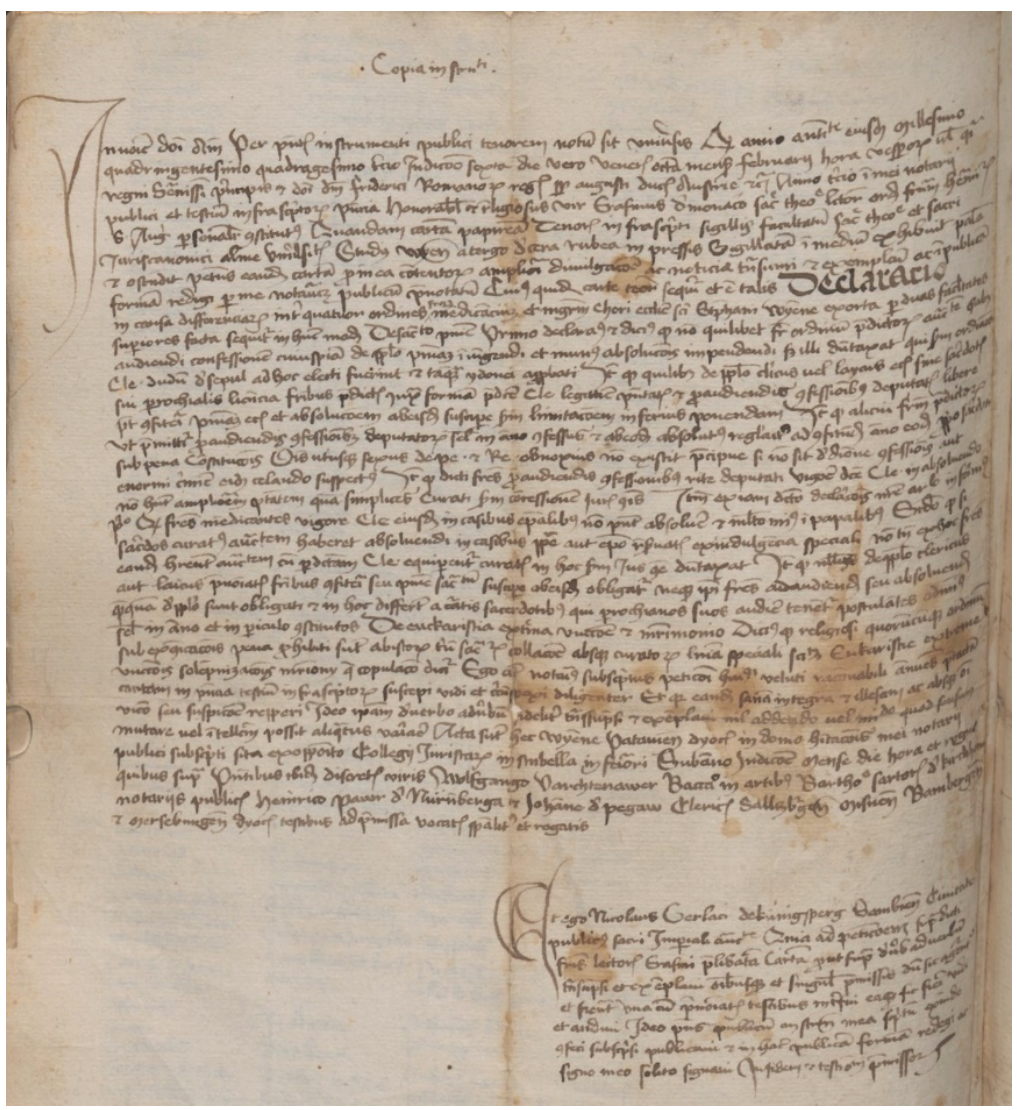

Fig. 2: Charter 1443, presented by Erasmus Gunther de Monaco, A-Wn, Cod. 5094, f. 136v ('Copia instrumenti'); (C) Vienna, Österreichische Nationalbibliothek.

\section{Transcription of the first section:}

In nomine domini... anno... 1443 indictione sexta [of Antipope Felix V.] 8 februarii, ...Friderici Romanorum regis anno tercio in mei notarii publici et testuum infrasciptorum presencia Honorabilis et religiosus vir Erasmus de monaco sacre theologie lector ordinis fratrum heremitarum S. Augustini personaliter constitutus Quandam cartam papiream Tenoris infrascripti sigillis facultatum sacre theologie et sacri Juris canonici alme universitatis Studiorum Wyennensis a tergo de cera rubea im pressis Sigillatam in medium exhibuit [...] cuius quidem carte tenor sequitur et est talis Declaracio [...] 
Summary of the document: On 8 February 1443 Erasmus de Monaco, OESA, Professor of Theology and Canon Law, presents to the public notary Nicolaus Gerlach and witnesses a charter sealed by the two faculties of Theology and Canon Law of Vienna University, on the dispute between the mendicant orders of Vienna and the magister chori of St Stephen's church [between 1439 and 1444: Lienhard Orthaber]. It is declared therein on what conditions the mendicant orders are allowed or disallowed to hear confessions, give absolution and spend the holy sacraments in the church of St Stephen. Essentially, these sacramental actions are permitted only to approved members of the four orders with special and personal permission of the church authorities of St Stephen's. The sacraments of the eucharist, extreme unction and marriage, in particular, require the special permission of the curates of the church. Abstract of the original document, signed by Notary Nicolaus Gerlacius of Nuremberg in the presence of named witnesses, in Vienna, 8 February 1443.

The 'honourable lector of canon law, the Austin friar Erasmus Gunther de Monaco', who announced the settling of the dispute, was most probably the one who struck the deal as an external referee or judge. He was at the time a lector sacre pagine et professor, becoming Prior of the Munich house c.1444, and Provincial of the Bavarian-Austrian province in 1448, succeeding Georg von Schöntal; having distinguished himself as a monastic reformer, he died c.1461, being succeeded by Johannes Ludovici, who then was the studiorum regens of the Augustinian friars at Vienna. ${ }^{29}$ I propose that the miscellaneous collection of the main part of Cod. 5094, which focuses on canonic and practical interests of the Augustinians, belonged to Erasmus Gunther, to whom it provided much useful material of canon law to guide his activity in disputes such as the one of 1443 . But did the musical appendix also belong to him? How did it become associated with the main corpus?

We must assume that, at some stage, the manuscript material of both sections existed as loose leaves. It is not known when the present two sections were bound together: this is most unlikely to have happened in 1752, or even in the sixteenth century, because adding a group of old music leaves to a canonistic miscellany would have contradicted the principles of the respective academic libraries. The fact that one leaf belonging to the first section of the corpus ended up bound amidst the music (f. 156) implies that the musical material was not even bound together as a single unit before it became part of the main codex: rather, at an early stage all the materials were bound or rebound together, having previously existed as scattered leaves or only gathered in fascicles. At that time, also

29 Catalogus 1729, 12. 
some of the losses of single leaves can easily have occurred. Thus, the musical collection was not a fragment, nor an assembly of fragments, but a collection of discreet musical items for the interests of organists and their friends. Who, however, would have wanted to keep these leaves together, and for what reason? Was Erasmus himself interested in the music, or was this a later owner?

The youngest documents in the collection, both dated 1463, were probably added by the person who inherited the manuscript material from Erasmus (d. c.1461). This person may have been Johannes Ludovici, studiorum regens in the Vienna convent and in 1461 successor to Erasmus as Provincial of the order, or Ludovici's successor as Provincial in 1468, who was then lector in the Vienna convent, too: he was Paulus Weygel de Monaco, an addressee of a letter dated 1460 in Cod. 5094 (f. 147r) and author of a charter issued in Munich, 1463 (f. 137v). However, in the 1460s, the musical appendix dating from the 1440s cannot have been of much interest even to amateur musicians among the friars. And, why would they have chosen to add old music to a miscellany of canon law and bind it all together? It seems to me that Erasmus Gunther himself (or a musician closely associated with him) was really the one interested in the music, which was contemporary to his visit to Vienna in 1443 , and that his entire collection of canonistic and musical manuscript materials was left to his successors together. No music more recent than the 1440 s was added, whereas the material of the main corpus was expanded when Erasmus had returned to Munich. That both his successors were lectors at the Vienna convent in the 1460s, readily explains why the codex was returned to, or remained at, Vienna.

There is also strong evidence that the musical material itself was linked to Erasmus Gunther. The evidence is one of the unica, a two-voice mensural composition on the last folio, f. $164 \mathrm{r} .{ }^{30}$ The text is cancelled, but it is possible to transcribe most of it, which is as follows:

Vivat nobilis prosapie inclitus iudex Erasmus, francisci familie ${ }^{*}$ quia quisque* fidus meritus, Totum quod est si ${ }^{*}$ cernas ponit* ut $^{*}$ alter munificus ${ }^{*}$

Primogenitoribus mercantibus exivit.

Quemque francisce optime tuo munimine

fac tue gracie pariterque participem glorie. ${ }^{31}$

Long live the renowned judge, Erasmus, of noble descent, because of his merit (fidus meritus) for the family of St Francis [of Assisi]. [Line 3: uncertain] He abandoned his parents,

30 Facsimile in $<$ https://musical-life.net/mediengalerie $>$.

$31 \star^{\star}{ }^{\star}$ : uncertain readings. fidus: added above the line, perhaps replacing *quisque ${ }^{\star}$. 
merchants [to become a friar]. Dearest Franciscus, make him through your protection a participant of your mercy and equally of your glory. (Translated by the author)

Judge Erasmus is being praised by the Franciscan friars, who benefited as much as did the Augustinians, the Carmelites and the Dominicans from the agreement with St Stephen's in 1443. The common ground of Austin and Franciscan friars in this context was the University of Vienna. Some musician composed a fairly competent two-voice setting of this celebratory text; the piece was added to the collection but the text was then cancelled, whether by Erasmus himself (out of modesty?) or by a later owner (out of jealousy?). The musical and notational style of this piece are compatible with those of the younger section of the St Emmeram codex, of $c .1440-1443$ (see music example in appendix). Erasmus Gunther may have been a musician himself, perhaps an organist. While in Vienna he would have had contact with local organists, at the Augustinian house in particular, who gave him specimens of their musical exercises; others sent them to him in letter form. Yet, if Erasmus was himself a specialised musician, would he not have added more music after the 1440s? Perhaps he turned away from the worldly pursuit of music when he became a monastic reformer. ${ }^{32}$

Whether Erasmus was a musician or an amateur, the musical items may well have been assembled at Vienna in 1443 and perhaps on other visits of those years, which Erasmus must have spent at the Austin friary in the city.

There are many possible names we could give to Cod. 5094: in both its main part and its musical appendix it was an anthology, a zibaldone, a commonplace book or a vademecum. But the music collection also served its owner as a 'souvenir de Vienne': as an anthology of the varied skills of organists in sacred institutions of Vienna in the 1440s. The individual components are not the surviving fragments of one larger whole (disiecta membra), nor haphazardly assembled pieces from many larger entities, but interrelated examples of a collective art. That some of them are accidentally no longer complete in themselves, may make them unfit for re-performance, but does not delete their function of artistic (and didactic) testimonies. This anthology aids the remembrance of a personal past, and even illustrates a moment of musical history.

32 It seems that the original owner of the so-called Lochamer Liederbuch, Judocus von Windsheim, abandoned work on his music collection when he entered the Augustinian friary of Windsheim around 1460. See Salmen/Petzsch 1972 and Lewon 2018. 


\section{References}

Catalogus priorum provincialium Ord. Erem. S. Augustini per provinciam, Munich: Riedlin, 1729.

Crane, Frederick (1965), '15th-Century Keyboard Music in Vienna MS 5094', in Journal of the American Musicological Society, 18: 237-245.

Cuthbert, Michael Scott (2010), 'The Nuremberg and Melk Fragments and the International Ars Nova', in Studi Musicali. Nuova serie, 1/1: 7-51.

Fallows, David (1987), Dufay, London: J.M. Dent [revised paperback].

Göllner, Theodor (1967), 'Notationsfragmente aus einer Organistenwerkstatt des 15. Jahrhunderts', in Archiv für Musikwissenschaft, 24: 170-177.

Lewon, Marc (2018), Reworkings: Transformational Practices in Fifteenth-Century German Music, Ph.D. dissertation, Oxford University.

Mantuani, Josef (ed.) (1864-1899), Tabulae codicum manuscriptorum praeter Graecos et orientales in Bibliotheca Palatina Vindobonensi asservatorum, 10 vols, Vienna: Gerold.

Pietzsch, Gerhard (1971), Zur Pflege der Musik an den deutschen Universitäten bis zur Mitte des 16. Jahrhunderts, Hildesheim: Olms.

Ristory, Heinz (1985), 'Notationstechnische Modifikationen von Vokalvorlagen im Codex Vind. 5094 der Österreichischen Nationalbibliothek (Wien)', in Musica Disciplina, 39: 53-86.

Rumbold, Ian, and Peter Wright (2009), Hermann Pötzlinger's Music Book: The St Emmeram Codex and its Contexts, Woodbridge: Boydell.

Salmen, Walter, and Christoph Petzsch (eds) (1972), Das Lochamer Liederbuch (Denkmäler der Tonkunst in Bayern, N.F., Sonderbd. 2), Wiesbaden: Breitkopf \& Härtel.

Shields, Michael (2011), “'Hidden polyphony” bei Oswald von Wolkenstein. Der Reihen “Ir alten weib” (KI 21)', in Christoph März, Lorenz Welker, and Nicola Zotz (eds), 'leglicher sang sein eigen ticht'. Germanistische und musikwissenschaftliche Beiträge zum deutschen Lied im Mittelalter, Wiesbaden: Reichert, 131-147.

Strohm, Reinhard (1966), 'Neue Quellen zur liturgischen Mehrstimmigkeit des Mittelalters in Italien', in Rivista Italiana di Musicologia, 1: 77-87.

Strohm, Reinhard (1984), 'Native and Foreign Polyphony in Late Medieval Austria', in Musica Disciplina, 38: 205-230.

Strohm, Reinhard (1993), The Rise of European Music, 1380-1500, Cambridge: Cambridge University Press.

Van Biezen, Jan, and Kees Vellekoop (1984), 'Aspects of Stroke Notation in the Gruuthuse Manuscript and other Sources', in Tijdschrift van de Vereniging voor Nederlandse muziekgeschiedenis, 34: 3-25. 
260

Reinhard Strohm

Appendix
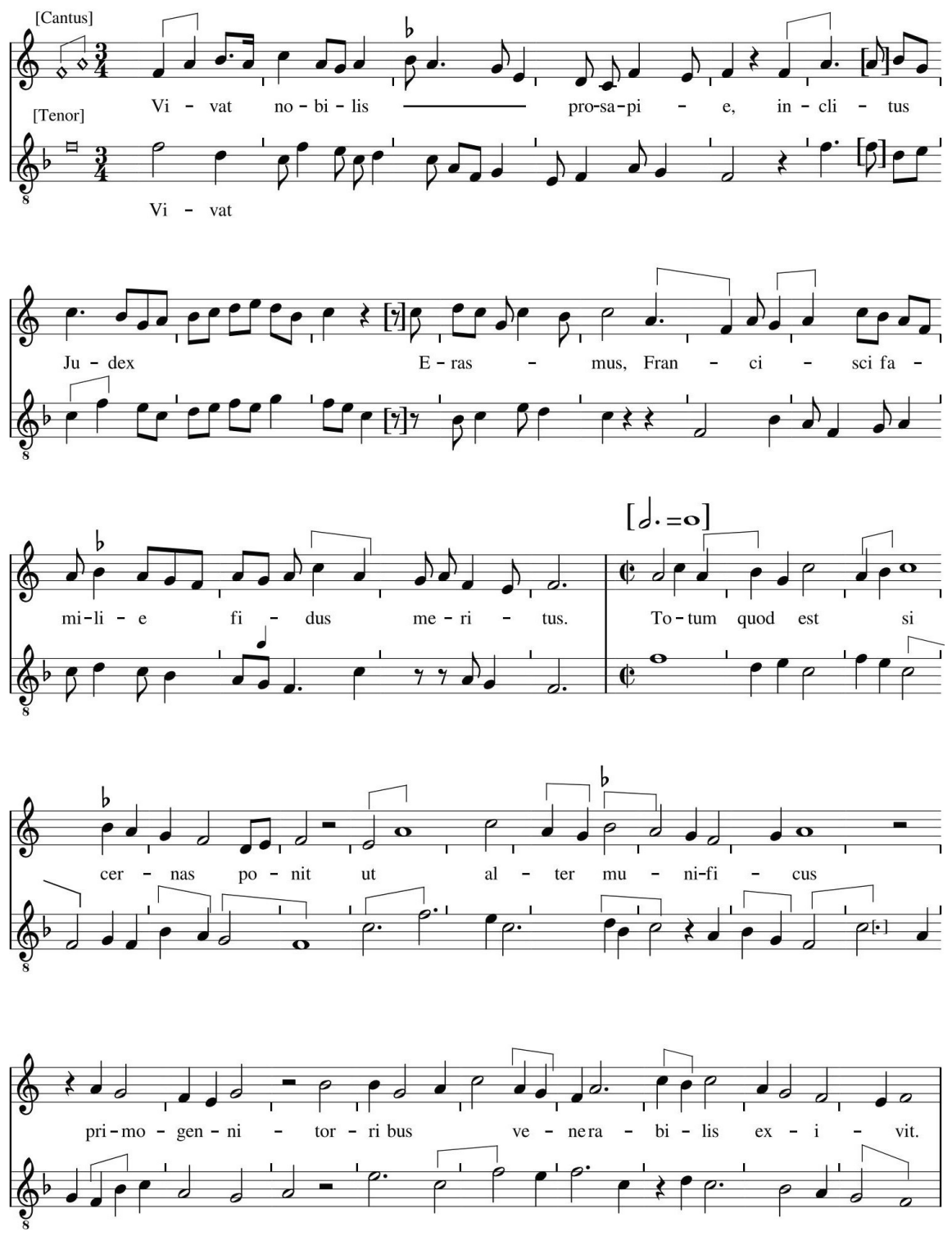

Music example: Vivat nobilis prosapie Cod. 5094, f. 164r. (Transcription by R. Strohm and B. Strohm, p. 1). 

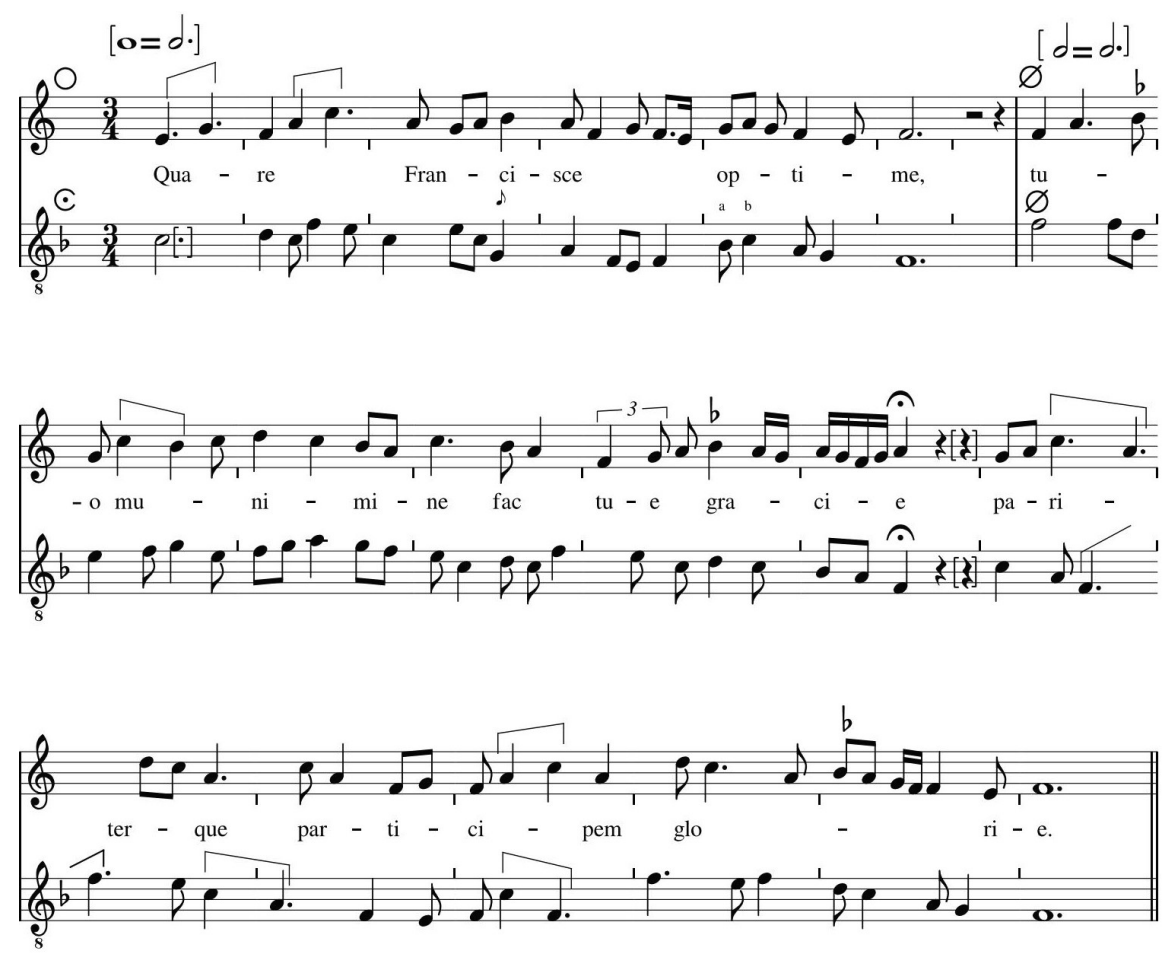

Music example: Vivat nobilis prosapie Cod. 5094, f. 164r. (Transcription by R. Strohm and B. Strohm, p. 2). 
